\title{
ANALYSIS OF FACTORS INHIBITING THE DEVELOPMENT OF COOPERATIVE STUDENTS OF BINA BEURATA FACULTY OF ECONOMICS UNIVERSITAS MALIKUSSALEH
}

\author{
Rahmaniar \\ Faculty of Economics and Business, Universitas Malikussaleh \\ E-mail: rahmaniar@unimal.ac.id
}

\begin{abstract}
This study aims to analyze the influence of internal factors and external factors to hinder the development of cooperatives. This study uses primary data in the form of a 2020 weekly report which is accessed on www.indodax.com. The method of internal data analysis is research data obtained directly from the original source which is carried out using a questionnaire that is processed using SPSS 20 (Statistical Package For Social Science). The results of the study partially show thatInternal factors have a significant effect on inhibiting the development of the Bina Beurata Student Cooperative, Faculty of Economics, Universitas Malikussaleh. External factors have a significant effect on inhibiting the development of the Bina Beurata Student Cooperative, Faculty of Economics, Universitas Malikussaleh. Variable internal factors and external factors in inhibiting the development of cooperatives is 0.362 or $36.2 \%$, while the remaining $63.8 \%$ is influenced by other variables not included in this study.
\end{abstract}

Keywords: Internal factors, external factors, hinder the development of cooperatives

\section{INTRODUCTION}

Indonesia is a developing country, its economic condition is also still not stable. One of the factors that influenced the instability of the Indonesian economy was when the global crisis hit. The global crisis has haunted the economy in small countries, one of which is Indonesia. The Government of the Republic of Indonesia in this decade has implemented and intensified the community to become entrepreneurs and cooperatives. In the presentation delivered by the President of the Republic of Indonesia, in 2012 at the international level, cooperatives have been recognized as an organization that is proven to be able to support economic growth, create jobs, strengthen social integrity and increase resilience to economic crises.

Cooperatives according to Law no. 25 of 1992 is a business entity consisting of one person or a cooperative legal entity by basing its activities on the cooperative principle as well as a people's economic movement based on the principle of kinship. Referring to Law Number 25 of 1992, the principles of cooperatives are that membership is voluntary and open, management is carried out democratically, SHU distribution is carried out fairly in proportion to the amount of business services of each member, limited remuneration for capital, independence, cooperative education and cooperation between cooperatives.

Cooperatives and SMEs are a form of business that is currently easy to find among the Acehnese people, both from urban communities and rural communities. In academia, such as in universities or colleges, student motivation to run cooperatives and SMEs has become part of the curriculum because it is considered one of the best solutions to foster interest in entrepreneurship. Therefore, currently cooperatives are easy to find among college students such as at Malikusaleh University.

Bina Beurata Student Cooperative, is the only cooperative in the Faculty of Economics, Universitas Malikussaleh which was established based on the ratification of the Cooperative Establishment Deed with Decree number 46/BH/KDK.1.3/IX/2001 on September 26, 2001. May 
2009, this cooperative still survives to this day. However, so far, there are no visible signs showing the development of the Bina Beurata cooperative, both in terms of business development, business capital, number of members and creativity of its membership.

Until now, the student cooperative of Bina Beurata, Faculty of Economics, Universitas Malikussaleh has not shown significant development. According to statements from several members of the Bina Beurata cooperative, the main problem faced by members of the Bina Beurata student cooperative at this time is that they have never felt the benefits of sharing the remaining operating results (SHU). The Bina Beurata Cooperative also does not have good financial reports. So that the projected profit and loss for each period is not known. In fact, from the canteen business that is run, every day they get an average daily income of Rp. 400,000, - up to Rp. 750.000,-.

External factors also have a negative impact if they are not part of the performance of the Bina Beurata student cooperative. Meanwhile, in external factors, the student cooperative of Bina Beurata Faculty of Economics Unimal still has not received in-depth support from various parties, including the campus and even the government. Even security conditions have been an obstacle in the development of the Bina Beurata student cooperative. Its existence in the campus environment is an advantage where the student cooperative of Bina Beurata Faculty of Economics Unimal only operates in potential fields such as photocopying and canteen business.

\section{LITERATURE REVIEW}

In an effort to obtain data, the authors use the field research method. One of the methods of research is directly carried out to the object of research to obtain primary data and other information needed in accordance with the problems to be discussed. The method included in this research is the distribution of questionnaires. Questionnaires were distributed directly by researchers to respondents who were selected as samples and confirmed to be members of the Bina Beurata Student Cooperative, Faculty of Economics, Universitas Malikussaleh.

\subsection{Business Development}

Business development is a qualitative and quantitative matter. Qualitative developments are business developments that cannot be described in nominal terms, but the direction of development can be explained. While quantitative business development can be described through increased sales, increased capital of a business and so on.

\subsection{Factors Affecting Cooperative Development \\ 2.2.1 Internal}

Internal factors that can affect the development of cooperatives are as follows:

a. Member Participation

b. Solidarity Between Cooperative Members

c. Scale enterprises

d. Capital Development

e. Managerial Skills

f. Market Network

g. Number and Quality of Human Resources for Managers and Managers

h. Ownership and Utilization of Production and Information Technology Equipment

i. Management system

j. Manager Performance

\subsubsection{External}

External factors that can affect the development of cooperatives are as follows:

a. The government's commitment to place cooperatives as the pillars of the national economy

b. Infrastructure, services, education and extension systems

c. A supportive climate for cooperative development 
d. Revocation of certain facilities by the government

e. Price level

\subsection{Research Framework}

According to Sudirman (2006:2), mentions the problems which are the factors that influence the development of cooperative businesses which include internal factors and external factors. Based on this opinion, the author can formulate an overview of the framework of thought in this study as follows:

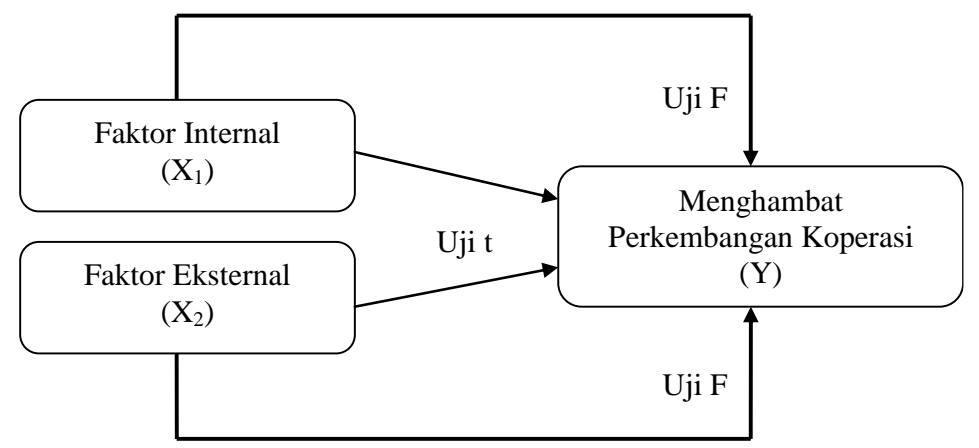

Figure 1 Research Framework

Through participation, all aspects related to the implementation of activities to achieve goals are realized. Stating that participation is developed to state or show the participation (participation) of a person or group of people in certain activities, while member participation in cooperatives means involving members of the cooperative in operational activities and achieving common goals. (Hendar and Kusnadi, 2005:91).

\subsection{Research Hypothesis}

H01: Suspected internal factors External dak does not have a significant effect in inhibiting the development of cooperatives of Bina Beurata Students, Faculty of Economics, Universitas Malikussaleh, either partially or simultaneously.

Ha1: Suspected internal factors No external influence significantly in inhibiting the development of cooperatives of Bina Beurata Students, Faculty of Economics, Universitas Malikussaleh, either partially or simultaneously.

This validity test is intended to test the research instrument. In this study, the validity of the instrument was tested on 25 respondents with several statements. The measured variables are said to be valid if the $r$ results $>r$ table (critical value) according to the number of samples used or the Pearson correlations value $>0.30$, Ghozali (2006: 46).

Reliability or reliability test shows the extent to which a measurement can provide results that are not different when repeated measurements are made on the same subject. The reliability test used is for one time data collection and to analyze the questionnaire whose scale is not 0 and 1, Cronbach's alpha formula is used, where an instrument is said to be reliable if Cronbach's alpha value is > 0.6 , (Ghozali, 2006: 42).

\section{RESEARCH METHODS}

\subsection{Research Location and Object}

This research was conducted at the Bina Beurata Student Cooperative, Faculty of Economics, Universitas Malikussaleh, Jalan Kalimantan, Bukit Indah Campus. While the object of this research are all members of the Student Cooperative of Bina Beurata Faculty of Economics, Universitas Malikussaleh, totaling 46 people. 


\subsection{Population and Sample}

The sampling method in this study uses saturated sampling (census), which is a sampling technique when all members of the population are used as samples because the population is small. Thus the number of samples in this study were 46 respondents. In determining the right respondent in providing data, using purposive sampling technique. Where the respondent is a structured member of the Bina Beurata Student Cooperative, Faculty of Economics, Universitas Malikussaleh.

\subsection{Data Types and Sources}

The source of the data used is primary data, namely research data obtained directly from the original source using a questionnaire. The questionnaire used in this study contains two main parts. The first part is about the characteristics of the respondents, containing respondent data related to the respondent's identity and social circumstances. While the second part is based on statements compiled based on research variables.

\subsection{Data collection technique}

In an effort to obtain data, the authors use the field research method. One of the methods of research is directly carried out to the object of research to obtain primary data and other information needed in accordance with the problems to be discussed. The method included in this research is the distribution of questionnaires. Questionnaires were distributed directly by researchers to respondents who were selected as samples and confirmed to be members of the Bina Beurata Student Cooperative, Faculty of Economics, Universitas Malikussaleh.

\subsection{Validity Test and Reliability Test}

This validity test is intended to test the research instrument. In this study, the validity of the instrument was tested on 25 respondents with several statements. The measured variables are said to be valid if the $r$ results $>r$ table (critical value) according to the number of samples used or the Pearson correlations value > 0.30, Ghozali (2006: 46).

Reliability or reliability test shows the extent to which a measurement can provide results that are not different when repeated measurements are made on the same subject. The reliability test used is for one time data collection and to analyze the questionnaire whose scale is not 0 and 1 , Cronbach's alpha formula is used, where an instrument is said to be reliable if Cronbach's alpha value is > 0.6, (Ghozali, 2006: 42).

\subsection{Classic assumption test}

The testing stages in the classical assumption test are Normality Test, Heteroscedasticity Test and Multicollinearity Test.

\subsection{Data analysis method}

In analyzing the data that aims to obtain data the authors of this study, the authors use quantitative methods.

\subsection{Data Measurement Technique}

In this study, researchers used a Likert scale data measurement technique, this scale was used to measure attitudes, opinions and perceptions of a person or group of people about social phenomena.

\subsection{Hypothesis test}

In this study, the hypothesis testing used is partial test ( $\mathrm{t}$ test) and simultaneous test ( $\mathrm{F}$ test).

\section{RESEARCH RESULTS AND DISCUSSION 4.1 Characteristics of Respondents}




\subsubsection{Respondent's Gender}

Table1 Respondent's Gender

\begin{tabular}{|c|c|c|c|c|c|}
\hline & & Frequency & Percent & Valid Percent & Cumulative Percent \\
\hline \multirow[t]{3}{*}{ Valid } & 1 & 32 & 69.6 & 69.6 & 69.6 \\
\hline & 2 & 14 & 30.4 & 30.4 & 100.0 \\
\hline & Total & 46 & 100.0 & 100.0 & \\
\hline
\end{tabular}

Source: research results. 2013

Based on table 1, it can be explained that male respondents were as many as 32 people or $69.6 \%$ of the total respondents and female respondents were 14 people or $30.4 \%$ of the total respondents. So it can be concluded that there are more male respondents than female respondents.

\subsubsection{Respondents Age Characteristics}

Table 2Age Characteristics Respondent

\begin{tabular}{|ll|r|r|r|r|}
\hline & Frequency & Percent & Valid Percent & Cumulative Percent \\
\hline Valid & 1 & 5 & 10.9 & 10.9 & 10.9 \\
& 2 & 18 & 39.1 & 39.1 & 50.0 \\
& 20 & 43.5 & 43.5 & 93.5 \\
& 3 & 6.5 & 6.5 & 100.0 \\
& & 3 & 100.0 & 100.0 & \\
\hline
\end{tabular}

Source: research results. 2013

Based on table 2, it can be explained that there are 5 respondents aged between 19-21 years or $10.9 \%$ of the total respondents. Respondents aged between $22-23$ years were 18 people or $39.1 \%$ of the total respondents. Respondents aged between $24-26$ years were 20 people or $43.5 \%$ of the total respondents and respondents aged over 26 years were 3 people or $6.5 \%$ of the total respondents. So it can be concluded that most respondents are aged between 24-26 years.

\subsubsection{Respondent Lecture Department}

Table 3Major Respondent

\begin{tabular}{|ll|r|r|r|r|}
\hline & Frequency & Percent & Valid Percent & Cumulative Percent \\
\hline Valid & 1 & 27 & 58.7 & 58.7 & 58.7 \\
& 2 & 12 & 26.1 & 26.1 & 84.8 \\
& 4 & 8.7 & 8.7 & 93.5 \\
& 4 & 6.5 & 6.5 & 100.0 \\
4 & 46 & 100.0 & 100.0 & \\
& Total & & & \\
\hline
\end{tabular}

Source: research results. 2013

Based on table 3, it can be explained that as many as 27 respondents or $58.7 \%$ are students majoring in Management. A total of 12 respondents or $26.1 \%$ were students majoring in Accounting. A total of 4 respondents or $8.7 \%$ were PDPK students and as many as 3 respondents or $6.5 \%$ of respondents were students of Development Economics. So it can be concluded that the majority of respondents came from the Department of Management. 
Analysis Of Factors Inhibiting The Development Of Cooperative Students Of Bina Beurata Faculty Of Economics Universitas Malikussaleh

DOI: $10.54443 /$ morfai.v1i2.68

\subsubsection{Respondent Lecture Semester}

Table 4Lecture Semester Respondent

\begin{tabular}{|ll|r|r|r|r|}
\hline & Frequency & Percent & Valid Percent & Cumulative Percent \\
\hline Valid & 1 & 1 & 2.2 & 2.2 & 2.2 \\
& 2 & 5 & 10.9 & 10.9 & 13.0 \\
& 2 & 4.3 & 4.3 & 17.4 \\
& & 32.6 & 32.6 & 50.0 \\
4 & 23 & 50.0 & 100.0 \\
8 & 46 & 100.0 & 100.0 & \\
& Total & & & \\
\end{tabular}

Source: research results. 2013

Based on table 4, it can be explained that as many as 1 respondent or $2.2 \%$ of respondents are students in semester 1 or 2 , as many as 5 respondents or $10.9 \%$ of respondents are students in semester 3 or 4 , as many as 2 respondents or $4.3 \%$ are 5th or 6th semester students, 15 respondents or $32.6 \%$ are 7 th or 8 th semester students and 23 respondents or $50 \%$ of respondents are alumni of the Faculty of Economics, Universitas Malikussaleh. So it can be concluded that the majority of respondents are alumni of the Faculty of Economics, Universitas Malikussaleh.

\subsection{Frequency of Research Variables \\ 4.2.1 Internal Factor Variable Frequency (X1)}

Table 5Internal Factor Variable Frequency

\begin{tabular}{|c|l|c|c|c|c|c|}
\hline \multirow{2}{*}{ Item Variabel } & Jawaban & STS & TS & N & S & SS \\
\hline \multirow{2}{*}{1} & Frekuensi & 0 & 0 & 7 & 33 & 6 \\
\cline { 2 - 7 } & Persentase & 0 & 0 & 15,2 & 71,7 & 13,0 \\
\hline \multirow{2}{*}{2} & Frekuensi & 0 & 0 & 7 & 35 & 4 \\
\cline { 2 - 7 } & Persentase & 0 & 0 & 15,2 & 76,1 & 8,7 \\
\hline \multirow{2}{*}{3} & Frekuensi & 0 & 0 & 14 & 28 & 4 \\
\cline { 2 - 7 } & Persentase & 0 & 0 & 30,4 & 60,9 & 8,7 \\
\hline \multirow{2}{*}{4} & Frekuensi & 0 & 0 & 7 & 34 & 5 \\
\cline { 2 - 7 } & Persentase & 0 & 0 & 15,2 & 73,9 & 10,9 \\
\hline \multirow{2}{*}{5} & Frekuensi & 0 & 0 & 9 & 29 & 8 \\
\cline { 2 - 7 } & Persentase & 0 & 0 & 19,6 & 63,0 & 17,4 \\
\hline
\end{tabular}

Source: research results. 2013

Based on table 5, it can be explained that for the first item the internal factor variable, as many as 7 respondents or $15.2 \%$ of respondents answered neutral, 33 respondents or $71.7 \%$ answered agree and 6 respondents or $13.0 \%$ of respondents answered strongly agree. For the second item of internal factor variables, as many as 7 people or $15.2 \%$ of respondents answered neutral, as many as 35 respondents or $76.1 \%$ answered agree and 4 respondents or $8.7 \%$ of respondents answered strongly agree. For the third item of internal factor variables, as many as 14 people or $30.4 \%$ of respondents answered neutral, 28 respondents or $60.9 \%$ answered agree and 4 respondents or $8.7 \%$ of respondents answered strongly agree. For the fourth item of internal factor variables, as many as 7 people or $15.2 \%$ of respondents answered neutral, as many as 34 respondents or $73.9 \%$ answered agree and 5 respondents or $10,9 \%$ of respondents answered strongly agree. For the fifth item of internal factor variables, 9 people or $19.6 \%$ of respondents answered neutral, 29 respondents or $63.0 \%$ answered agree and 8 respondents or $17.4 \%$ of respondents answered strongly agree. From the explanation above, it can be concluded that the majority of respondents' answers are in agreement with all statement items on internal factor variables.

\subsubsection{Variable Frequency External Factor (X2)}




\section{ORFAI JOURNAL Actual and International Issue}

Table 6Variable Frequency External Factor

\begin{tabular}{|c|l|c|c|c|c|c|}
\hline Item Variabel & Jawaban & STS & TS & N & S & SS \\
\hline \multirow{2}{*}{1} & Frekuensi & 0 & 0 & 12 & 28 & 6 \\
\cline { 2 - 7 } & Persentase & 0 & 0 & 26,1 & 60,9 & 13,0 \\
\hline \multirow{2}{*}{2} & Frekuensi & 0 & 0 & 9 & 32 & 5 \\
\cline { 2 - 7 } & Persentase & 0 & 0 & 19,6 & 69,6 & 10,9 \\
\hline \multirow{2}{*}{3} & Frekuensi & 0 & 0 & 14 & 28 & 4 \\
\cline { 2 - 7 } & Persentase & 0 & 0 & 30,4 & 60,9 & 8,7 \\
\hline \multirow{2}{*}{4} & Frekuensi & 0 & 0 & 9 & 30 & 7 \\
\cline { 2 - 7 } & Persentase & 0 & 0 & 19,6 & 65,2 & 15,2 \\
\hline \multirow{2}{*}{5} & Frekuensi & 0 & 0 & 9 & 31 & 6 \\
\cline { 2 - 7 } & Persentase & 0 & 0 & 19,6 & 67,4 & 13,0 \\
\hline
\end{tabular}

Source: research results. 2013

Based on table 6, it can be explained that for the first item variable external factors, as many as 12 respondents or $26.1 \%$ of respondents answered neutral, 28 respondents or $60.9 \%$ answered agree and 6 respondents or $13.0 \%$ of respondents answered strongly agree. For the second item variable external factors, as many as 9 people or $19.6 \%$ of respondents answered neutral, as many as 32 respondents or $69.6 \%$ answered agree and 5 respondents or $10.9 \%$ of respondents answered strongly agree. For the third item variable external factors, as many as 14 people or $30.4 \%$ of respondents answered neutral, 28 respondents or $60.9 \%$ answered agree and 4 respondents or $8.7 \%$ of respondents answered strongly agree. For the fourth item variable external factors, as many as 9 people or $19.6 \%$ of respondents answered neutral, as many as 30 respondents or $65.2 \%$ answered agree and 7 respondents or $15,2 \%$ of respondents answered strongly agree. For the fifth item of external factor variables, 9 people or $19.6 \%$ of respondents answered neutral, 31 respondents or $67.4 \%$ answered agree and 6 respondents or $13.0 \%$ of respondents answered strongly agree. From the explanation above, it can be concluded that the most respondents' answers are in agreement with all statement items on external factor variables.

\subsubsection{Variable Frequency Inhibits Cooperative Development (Y)}

Table 7Variable Frequency Inhibits Cooperative Development

\begin{tabular}{|c|l|c|c|c|c|c|}
\hline Item Variabel & Jawaban & STS & TS & N & S & SS \\
\hline \multirow{2}{*}{1} & Frekuensi & 0 & 0 & 9 & 31 & 6 \\
\cline { 2 - 7 } & Persentase & 0 & 0 & 19,6 & 67,4 & 13,0 \\
\hline \multirow{2}{*}{2} & Frekuensi & 0 & 0 & 7 & 32 & 7 \\
\cline { 2 - 7 } & Persentase & 0 & 0 & 15,2 & 69,6 & 15,2 \\
\hline \multirow{2}{*}{3} & Frekuensi & 0 & 0 & 16 & 24 & 6 \\
\cline { 2 - 7 } & Persentase & 0 & 0 & 34,8 & 52,2 & 13,0 \\
\hline \multirow{2}{*}{4} & Frekuensi & 0 & 0 & 10 & 30 & 6 \\
\cline { 2 - 7 } & Persentase & 0 & 0 & 21,7 & 65,2 & 13,0 \\
\hline \multirow{2}{*}{5} & Frekuensi & 0 & 0 & 12 & 27 & 7 \\
\cline { 2 - 7 } & Persentase & 0 & 0 & 26,1 & 58,7 & 15,2 \\
\hline
\end{tabular}

Source: research results. 2013

Based on table 4.7, it can be explained that for the first item the variable hinders the development of cooperatives, as many as 9 respondents or $19.6 \%$ of respondents answered neutral, 31 respondents or $67.4 \%$ answered agree and 6 respondents or $13.0 \%$ of respondents answered strongly agree. For the second item, the variable hinders the development of cooperatives, as many as 7 people or $15.2 \%$ of respondents answered neutral, 32 respondents or $69.6 \%$ answered agree and 7 respondents or $15.2 \%$ of respondents answered strongly agree. For the third item, the variables hinder the development of cooperatives, as many as 16 people or $34.8 \%$ of respondents answered neutral, 24 respondents or $52.2 \%$ answered agree and 6 respondents or $13.0 \%$ of respondents 
answered strongly agree. For the fourth item, the variables hinder the development of cooperatives, as many as 10 people or $21.7 \%$ of respondents answered neutrally, as many as 30 respondents or $65.2 \%$ answered agree and 6 respondents or $13.0 \%$ respondents answered strongly agree. For the fifth item, the variables hindering the development of cooperatives, as many as 12 people or $26.1 \%$ of respondents answered neutrally, as many as 27 respondents or $58.7 \%$ answered agree and 7 respondents or $15.2 \%$ of respondents answered strongly agree. From the explanation above, it can be concluded that the majority of respondents' answers are in agreement with all statement items on the variables that hinder the development of cooperatives.

\subsection{Validity Test Results and Reliability Test 4.3.1 Validity Test Results}

Table 8Validity Test Results

\begin{tabular}{|c|c|c|c|}
\hline \multirow{2}{*}{ Variabel } & Item & Pearson Correlation & Keterangan \\
\hline \multirow{4}{*}{$\begin{array}{c}\text { Faktor Internal } \\
\left(\mathrm{X}_{1}\right)\end{array}$} & 1 & 0,629 & Valid \\
\cline { 2 - 4 } & 2 & 0,745 & Valid \\
\cline { 2 - 4 } & 3 & 0,567 & Valid \\
\cline { 2 - 4 } & 4 & 0,715 & Valid \\
\cline { 2 - 4 } & 5 & 0,642 & Valid \\
\hline \multirow{3}{*}{$\begin{array}{c}\text { Faktor Eksternal } \\
\left(\mathrm{X}_{2}\right)\end{array}$} & 1 & 0,349 & Valid \\
\cline { 2 - 4 } & 2 & 0,832 & Valid \\
\cline { 2 - 4 } & 3 & 0,531 & Valid \\
\cline { 2 - 4 } & 5 & 0,691 & Valid \\
\cline { 2 - 4 } & 1 & 0,768 & Valid \\
\cline { 2 - 4 } Menghambat \\
\cline { 2 - 4 } Perkembangan Koperasi & 2 & 0,894 & Valid \\
\cline { 2 - 4 }$(\mathrm{Y})$ & 3 & 0,609 & Valid \\
\cline { 2 - 4 } & 4 & 0,590 & Valid \\
\hline
\end{tabular}

Source: research results. 2013

Based on table 8 , it can be explained that all items contained in the research questionnaire have a Pearson correlation value above 0.30 . So it can be concluded that all existing items are feasible and can be used as a tool to obtain research data.

\subsubsection{Reliability Test Results}

Table 9Reliability Test Results

\begin{tabular}{|l|c|c|}
\hline \multicolumn{1}{|c|}{ Variabel } & Alpha Cronbach & Keterangan \\
\hline Faktor Internal $\left(\mathrm{X}_{1}\right)$ & 0,782 & Reliabel \\
\hline Faktor Eksternal $\left(\mathrm{X}_{2}\right)$ & 0,748 & Reliabel \\
\hline Menghambat Perkembangan Koperasi $(\mathrm{Y})$ & 0,825 & Reliabel \\
\hline
\end{tabular}

Source: research results. 2013

Based on table 9, it is known that for the internal factor variable (X1) the Cronbach's alpha value is $0.782>0.60$, for the external factor variable (X2) the Cronbach's alpha value is $0.748>0.60$ and for the variable inhibiting cooperative development $(\mathrm{Y})$ the value cronbach's alpha of $0.825>$ 0.60. All variables have a value greater than 0.60. So it can be concluded that the research questionnaire has met the requirements of reliability (reliable).

\subsection{Classic Assumption Test Results}

\subsubsection{Normality Test Results}

Based on table 10 below, it can be explained that the results of normality for each data distribution of the research variables, namely for the internal factor variable (X1) the significant value is $0.063>0.05$, the data distribution for the external factor variable (X2) the significant value is of 
$0.114>0.05$ and the distribution of data for the variable inhibiting the development of cooperatives (Y) the significant value is $0.078>0.05$. So it can be concluded that all data are normally distributed.

Table 10 Normality Test Results

\begin{tabular}{|c|c|c|c|c|}
\hline \multicolumn{5}{|c|}{ One-Sample Kolmogorov-Smirnov Test } \\
\hline & & $\mathrm{x} 1$ & $x 2$ & y \\
\hline \multicolumn{2}{|l|}{$\mathrm{N}$} & 46 & 46 & 46 \\
\hline \multirow[t]{2}{*}{ Normal Parameters ${ }^{a}$} & Mean & 3.93 & 3.89 & 3.90 \\
\hline & Std. Deviation & .346 & .339 & .427 \\
\hline \multirow[t]{3}{*}{ Most Extreme Differences } & Absolute & .220 & .176 & .216 \\
\hline & Positive & .220 & .135 & .216 \\
\hline & Negative & -.119 & -.176 & -.121 \\
\hline Kolmogorov-Smirnov Z & & 1.491 & 1.197 & 1.464 \\
\hline Asymp. Sig. (2-tailed) & & .063 & .114 & .078 \\
\hline & & & & \\
\hline
\end{tabular}

Source: research results. 2013

\subsubsection{Heteroscedasticity Test Results}

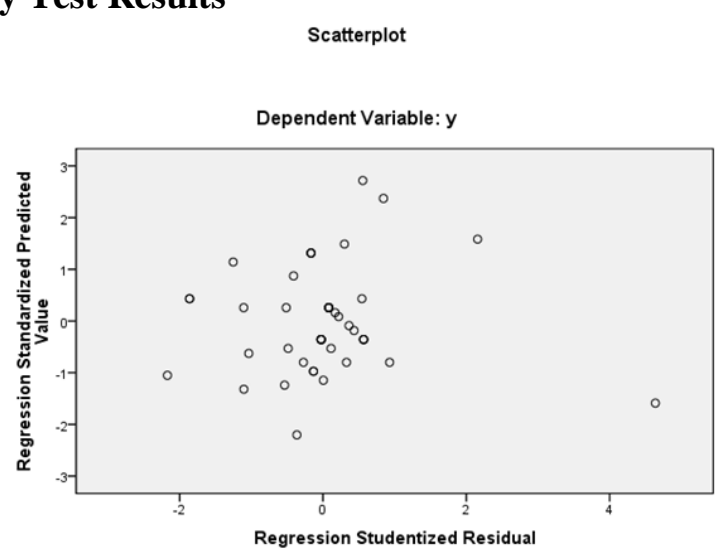

Source: research results. 2013

Figure 2 Heteroscedasticity Test Results

Based on Figure 2, it can be explained that the scatterplot image above shows the distribution of points randomly and does not form a clear pattern, and the distribution is above and below the number 0 on the $\mathrm{Y}$ axis. otherwise it can be concluded that the regression model is feasible to use to measure the influence of internal and external factors in inhibiting the development of the Bina Beurata Student Cooperative.

\subsubsection{Multicollinearity Test Results}

Table 11 Multicollinearity Test Results

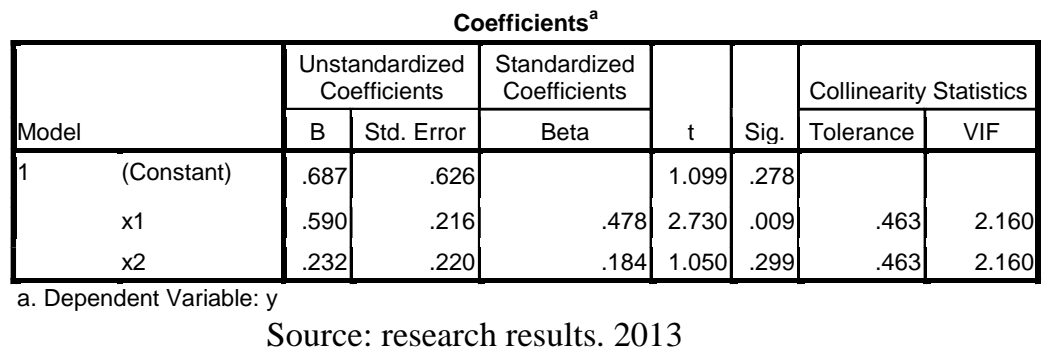

Based on table 11, it can be explained that the internal factor variable has a tolerance value of $0.463>0.10$ and a VIF value of $2.160<10$ and for external factor variables the tolerance value is 
Analysis Of Factors Inhibiting The Development Of Cooperative Students Of Bina Beurata Faculty Of Economics Universitas Malikussaleh

DOI: $10.54443 /$ morfai.v1i2.68

$0.463>0.10$ and a VIF value of $2.160<10$. So it can be concluded the regression model is declared good because there is no correlation between the independent variables.

\subsection{Discussion}

\subsubsection{Correlation Coefficient (R) and Determination Coefficient (R2)}

Table 12 Guidelines for Interpreting Correlation Coefficients (R)

\begin{tabular}{|c|c|}
\hline Proyeksi Nilai Koefesien Korelasi & Interpretasi Koefesien Korelasi \\
\hline 1. $0,00 \mathrm{~s} / \mathrm{d} 0,199$ & 1. Sangat rendah \\
\hline 2. $0,20 \mathrm{~s} / \mathrm{d} 0,399$ & 2. Rendah \\
\hline 3. $0,40 \mathrm{~s} / \mathrm{d} 0,599$ & 3. Sedang \\
\hline 4. $0,60 \mathrm{~s} / \mathrm{d} 0,799$ & 4. Kuat \\
\hline 5. $0,80 \mathrm{~s} / \mathrm{d} 1,000$ & 5. Sangat kuat \\
\hline
\end{tabular}

Source: Sugiyono (2007) in Priyatno (2010:16)

The value of the correlation coefficient (R) and the coefficient of determination (R2) can be seen in the table below:

Table 4.13Correlation Coefficient (R) and Determination Coefficient (R2)

\begin{tabular}{|l|c|c|r|r|}
\hline Model & $\mathrm{R}$ & $\mathrm{R}$ Square & Adjusted R Square & Std. Error of the Estimate \\
\hline 1 & $.625^{\mathrm{a}}$ & .391 & .362 & .341 \\
\hline
\end{tabular}
a. Predictors: (Constant), $\mathrm{x} 2, \mathrm{x} 1$
b. Dependent Variable: $\mathrm{y}$

Source: research results. 2013

Based on the table above, it is known that the value of the correlation coefficient $(\mathrm{R})$ is 0.625 . This means that the relationship between internal factors (X1) and external factors (X2) in inhibiting the development of the Bina Beurata Student cooperative is 0.625 or $62.5 \%$. In other words, the relationship between internal factors (X1) and external factors (X2) in inhibiting cooperative development is strong and positive. While the value of the coefficient of determination (R2) is 0.362. This means that the ability of internal factor variables (X1) and external factors (X2) in inhibiting the development of cooperatives is 0.362 or $36.2 \%$, while the remaining $63.8 \%$ is influenced by other variables not included in this study.

\subsection{Multiple Linear Regression Analysis}

Table 14 Correlation Coefficient (R) and Determination Coefficient (R2)

Source: research results. 2013

\begin{tabular}{|c|c|c|c|c|c|c|c|c|}
\hline \multicolumn{9}{|c|}{ Coefficients $^{a}$} \\
\hline \multirow{2}{*}{\multicolumn{2}{|c|}{ Model }} & \multicolumn{2}{|c|}{$\begin{array}{c}\text { Unstandardized } \\
\text { Coefficients }\end{array}$} & \multirow{2}{*}{$\begin{array}{c}\begin{array}{c}\text { Standardized } \\
\text { Coefficients }\end{array} \\
\text { Beta }\end{array}$} & \multirow[b]{2}{*}{$\mathrm{t}$} & \multirow[b]{2}{*}{ Sig. } & \multicolumn{2}{|c|}{ Collinearity Statistics } \\
\hline & & B & Std. Error & & & & Tolerance & VIF \\
\hline \multirow[t]{3}{*}{1} & (Constant) & .687 & .626 & & 1.099 & .278 & & \\
\hline & $\mathrm{x} 1$ & .590 & .216 & .478 & 2.730 & .009 & .463 & 2.160 \\
\hline & $x 2$ & .232 & .220 & .184 & 1.050 & .299 & .463 & 2.160 \\
\hline
\end{tabular}

Based on the table above, multiple linear regression equations can be formed as follows: $\mathrm{Y}=$ $0.687+0.590 \mathrm{X} 1+0.232 \mathrm{X} 2$

Based on this equation, it can be explained that the constant value is 0.687 , which means that if the variables of internal factors and external factors are considered constant or the value is 0 , then it hinders the development of the Bina Beurata Student cooperative by 0.687 . The coefficient of the internal factor variable is 0.590 , meaning that if the internal factor indicators are increased by $100 \%$, 


\section{ORFAI JOURNAL Multidiciplinary Output Research For Actual and International Issue}

it will hinder the development of the Bina Beurata Student Cooperative to increase by 0.590 or $59.0 \%$.

The coefficient of the external factor variable is 0.232 , which means that if the external factor indicators are increased by $100 \%$, it will hinder the development of the Bina Beurata Student cooperative to increase by 0.232 or $23.2 \%$.

\subsection{Hypothesis Testing Results}

\subsubsection{Simultaneous Test Results (F Test)}

Table 15 Simultaneous Test Results (F Test)

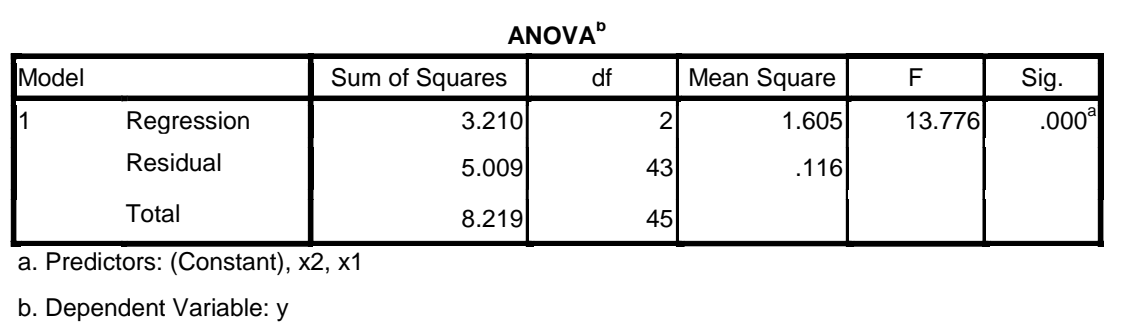

Source: research results. 2013

Based on table 15, it is known that the Fcount value is 13.776 with a significant level of 0.00 . While the value of Ftable at 5\% (0.05) is determined by using the formula df1 and df 2 . Df $1=$ number of variables-1 $(3-1=2)$ while Df2 $=$ nk-1 $(46-2-1=43)$, then the value of Ftable is 3,214. This means that Fcount $>$ Ftable or 13,776 > 3,214, it can be concluded that simultaneously the internal factor variables (X1) and external factors (X2) have a significant effect in inhibiting the development of the Bina Beurata Student cooperative, Faculty of Economics, Universitas Malikussaleh.

\subsubsection{Hypothesis Test Results (Partial Test)}

Table 16 Simultaneous Test Results (F Test)

\begin{tabular}{|c|c|c|c|c|c|c|c|c|}
\hline \multicolumn{9}{|c|}{ Coefficients $^{a}$} \\
\hline \multirow{2}{*}{\multicolumn{2}{|c|}{ Model }} & \multicolumn{2}{|c|}{$\begin{array}{l}\text { Unstandardized } \\
\text { Coefficients }\end{array}$} & \multirow{2}{*}{$\begin{array}{c}\begin{array}{c}\text { Standardized } \\
\text { Coefficients }\end{array} \\
\text { Beta }\end{array}$} & \multirow[b]{2}{*}{$t$} & \multirow[b]{2}{*}{ Sig. } & \multicolumn{2}{|c|}{ Collinearity Statistics } \\
\hline & & B & Std. Error & & & & Tolerance & VIF \\
\hline \multirow[t]{3}{*}{1} & (Constant) & .687 & .626 & & 1.099 & .278 & & \\
\hline & $\mathrm{x} 1$ & .590 & .216 & .478 & 2.730 & .009 & .463 & 2.160 \\
\hline & $x 2$ & .232 & .220 & .184 & 1.050 & .299 & .463 & 2.160 \\
\hline
\end{tabular}

Source: research results. 2013

Based on table 16, it is known that the internal factor variable has a tcount value of 2.730 with a significant level of 0.00 and the external factor variable tcount value of 1.050 with a significant level of 0.29 . While the value of ttable is sought at $=5 \%: 2=2.5 \%(0.025)$ two-sided test with degrees of freedom $(\mathrm{df})=\mathrm{nk}-1(46-2-1=43)$, then the ttable is 2.017 . The explanation of the test results is as follows:

The internal factor variable has a value of $\mathrm{t}_{\text {count }}$ of 2.730 with a significant level of 0.00 while the ttable value is 2.017. Then tcount $>$ ttable or 2,730 > 2,017, meaning that the research results reject $\mathrm{HO}$ and accept $\mathrm{Hi}$. So it can be concluded that partially internal factors have a significant effect on inhibiting the development of the Bina Beurata Student Cooperative, Faculty of Economics, Universitas Malikussaleh.

The external factor variable has a value of $t_{\text {count }}$ of 1.050 with a significant level of 0.29 while the ttable value is 2.017 . Then tcount $<$ ttable or $1.050<2.017$, meaning that the research results reject $\mathrm{Hi}$ and accept $\mathrm{HO}$. So it can be concluded that partially external factors have no significant 
effect in inhibiting the development of the Bina Beurata Student Cooperative, Faculty of Economics, Universitas Malikussaleh.

\section{CONCLUSION}

Based on the results of the research described in the previous chapter, the conclusions in this study are as follows:

1. Based on the results of the study, it is known that the relationship between internal factors (X1) and external factors (X2) in inhibiting the development of the Bina Beurata Student cooperative is 0.625 or $62.5 \%$. The ability of internal factor variables (X1) and external factors (X2) in inhibiting the development of cooperatives is 0.362 or $36.2 \%$, while the remaining $63.8 \%$ is influenced by other variables not included in this study.

2. Based on the results of the study, it is known that Fcount $>$ Ftable or 13,776 > 3,214, it can be concluded that simultaneously the internal factor variables (X1) and external factors (X2) have a significant effect on inhibiting the development of the Bina Beurata Student cooperative, Faculty of Economics, Universitas Malikussaleh.

3. Based on the partial test results, the internal factor value tcount $>$ ttable or 2,730>2,017, meaning that internal factors have a significant effect on inhibiting the development of the Bina Beurata Student Cooperative, Faculty of Economics, Universitas Malikussaleh. External factor variable $t$ value $_{\text {count }}<\mathrm{t}$ table or $1.050<2.017$, meaning that external factors have no significant effect in inhibiting the development of the Bina Beurata Student Cooperative, Faculty of Economics, Universitas Malikussaleh.

\section{REFERENCES}

Boediono. (2004). Research Methods Public Relations and Communication. Publisher: PT. King Grafindo Persada. Jakarta

Laws of the republic Indonesia. Number 25 of 1992. Regarding Cooperatives. President of the Republic of Indonesia

Djojohadikoesoemo, Margono. (2002). 10 Years of Cooperative 1941. Publisher: Alfabeta. Bandung

Julia, Wasa. Kusrini, Endah, Dwi. (2009). Analysis of Student Characteristics and Factors Influencing ITS Student Independent Business Ownership. Journal of Statistics FMIPA. Ten November Institute of Technology. Surabaya

Journal of the Study of Cooperatives and SMEs no. 1 year 2006

Liana April. (2010). Factors Affecting Remaining Operating Results at the Waru Buana Putra Cooperative in Sidoarjo

Majied Sumatrani Saragih, M. ., Hikmah Saragih, U. ., \& Nur Ilham, R. . (2021). RELATIONSHIP BETWEEN MOTIVATION AND EXTRINSIC MOTIVATION TO ICREASING ENTREPRENEURSHIP IMPLEMENTATION FROM SPP AL-FALAH GROUP AT BLOK 10 VILLAGE DOLOK MASIHUL. MORFAI JOURNAL, 1(1), 1-12. https://doi.org/10.54443/morfai.v1i1.11

cashmere. (2003). Influence of Entrepreneurial Behavior of Publisher PT. Raja Grafindo Persada, Jakarta

Ghozali, Imam. (2006). "Multivariate Application With SPSS Program”, Edition II. Diponegoro University Publishing Agency

Hasan, Hamid, Said. (1997). Introduction to Business Administration, Business Environment. Brawijaya University

Haryadi (2008). Strategic Management and Corporate Policy, transliterated: Murad and AR. Henry Sitanggang, third edition, Erlangga, Jakarta

Hendar and Kusnadi. (2005). The Influence of the Business Environment on the Performance of Batik Industry Craftsmen in Bangkalan Regency. Journal of Economic Partners and Business 
Management, Vol.1, No. 2, October 2010, 152-162 ISSN 2087-1090. Faculty of Economics, Trunojoyo University. Madura

Character. (2004). Understanding Entrepreneurship, Jakarta

Priyatno, Duwi. (2010). "Understand Statistical Analysis of Data with SPSS". MediaKom. Yogyakarta

Raharja, Hanang Slamet. 2019. Cultivation of Oil Palm Plants. West Jakarta : PT Sunda Kelapa Pustaka.

Sandi, H. ., Afni Yunita, N. ., Heikal, M. ., Nur Ilham, R. ., \& Sinta, I. . (2021). RELATIONSHIP BETWEEN BUDGET PARTICIPATION, JOB CHARACTERISTICS, EMOTIONAL INTELLIGENCE AND WORK MOTIVATION AS MEDIATOR VARIABLES TO STRENGTHENING USER POWER PERFORMANCE: AN EMPERICAL EVIDENCE FROM INDONESIA GOVERNMENT. MORFAI JOURNAL, 1(1), 36-48. https://doi.org/10.54443/morfai.v1i1.14

Schumpeter. (2003). Scope of Entrepreneurship. Erlangga: Jakarta

Sugiyono. (2004). Quantitative, Qualitative and R\&D Research Methods. Publisher: Alphabeta. Bandung

Sudirman. (2006).Entrepreneurship: Practical Guide, Tips and Process to Success. Salemba Empat, Jakarta 
Volumes 1 No 2 (2021)

Analysis Of Factors Inhibiting The Development Of Cooperative Students Of Bina Beurata Faculty Of Economics Universitas Malikussaleh

DOI: $10.54443 /$ morfai.v1i2.68 